\title{
COMPUTERS AND STUDENT LEARNING: BIVARIATE AND MULTIVARIATE EVIDENCE ON THE AVAILABILITY AND USE OF COMPUTERS AT HOME AND AT SCHOOL
}

\author{
THOMAS FUCHS \\ LUDGER WOESSMANN
}

CESIFO WORKING PAPER NO. 1321

CATEGORY 4: LABOUR MARKETS

NOVEMBER 2004

An electronic version of the paper may be downloaded

- from the SSRN website: Www.SSRN.com

- from the CESifo website: www.CESifo.de 


\title{
COMPUTERS AND STUDENT LEARNING: BIVARIATE AND MULTIVARIATE EVIDENCE ON THE AVAILABILITY AND USE OF COMPUTERS AT HOME AND AT SCHOOL
}

\begin{abstract}
We estimate the relationship between students' educational achievement and the availability and use of computers at home and at school in the international student-level PISA database. Bivariate analyses show a positive correlation between student achievement and the availability of computers both at home and at schools. However, once we control extensively for family background and school characteristics, the relationship gets negative for home computers and insignificant for school computers. Thus, the mere availability of computers at home seems to distract students from effective learning. But measures of computer use for education and communication at home show a positive conditional relationship with student achievement. The conditional relationship between student achievement and computer and internet use at school has an inverted U-shape, which may reflect either ability bias combined with negative effects of computerized instruction or a low optimal level of computerized instruction.
\end{abstract}

JEL Code: I2.

Keywords: computers at home, computers at school, student achievement, educational production, PISA.

Thomas Fuchs

Ifo Institute for Economic Research at the University of Munich

Poschingerstr. 5

81679 Munich

Germany

fuchs@ifo.de
Ludger Woessmann

Ifo Institute for Economic Research at the University of Munich

Poschingerstr. 5

81679 Munich

Germany

woessmann@ifo.de

Financial support by the Volkswagen Foundation for part of this research is gratefully acknowledged. 


\section{Introduction}

Computer use is deemed increasingly important in modern societies. Computers and the internet have introduced dramatic changes to work processes and to the organization of corporate structures over the past decade (cf. Lindbeck and Snower 2000). Computers and the internet have also changed the shopping and recreational behavior of households. Similarly, students are faced with computers both at home and at school, and governments worldwide have introduced schemes to equip schools with classroom computers and internet connections. This paper analyzes whether the availability and use of computers is related to students' educational achievement. We use the extensive student-level micro data from the Programme for International Student Assessment (PISA), an international student achievement test, to estimate the relationship between computers and student learning empirically. The PISA database offers information both about the availability and about the use of computers by students, both at home and at school.

We show that, first, bivariate evidence on the relationship between computers and students' educational achievement is highly misleading. Because computer availability at home is strongly correlated with other family-background characteristics, bivariate results on computer availability at home are severely biased. Still, simple bivariate correlations are what many commentators base their assessments on. Even high-quality documents such as the initial release of the PISA results, albeit cautioning about possible limitations to the interpretation of bivariate findings, reports the simple bivariate finding that "[s]tudents with higher values on the index of interest in computers tend to perform better on the combined reading literacy scale" (OECD 2001, p. 118). We show that the statistically significant positive correlation between the availability of computers at home and student performance in math and reading reverses into a statistically significantly negative one as soon as other family-background influences are extensively controlled for in multivariate regressions.

Second, similar to the case of computer availability at home, bivariate results on computer availability at school are severely biased because the availability of school computers is strongly correlated with the availability of other school resources. While the bivariate correlation between the availability of computers at school and student performance is strongly and statistically significantly positive, the correlation becomes small and statistically indistinguishable from zero once other school characteristics are held constant. The multivariate results illustrate how careless bivariate interpretations can lead to patently false conclusions. 
Third, we show that the relationship between computers and student learning differs strongly between the mere availability of computers and their use as a communicational and educational device. At home, the negative relationship of student performance with computer availability contrasts with positive relationships with the use of computers for emailing, webpage access and the use of educational software. Thus, the mere availability of computers at home seems to distract students from learning, presumably mainly serving as devices for playing computer games. Only by using computers in constructive ways can the negative effect of computer provision on student learning be partly compensated for.

Fourth, the relationship between student achievement and the use of computers and the internet at school shows an inverted U-shape. That is, students who never use computers or the internet at school show lower performance than students who sometimes use computers or the internet at school. But students who use them several times a week perform even lower. We offer two possible explanations for this pattern. On the one hand, teachers might refrain from using computers with students of a low ability level. Then, the first part of the pattern may simply reflect an ability bias, and the second part of the pattern may reflect that computer use might actually have decreased student learning, as has also been found in a previous quasi-experimental study (Angrist and Lavy 2002). On the other hand, assuming that there is no ability bias left after the extensive controls that we include in the regressions, the pattern might suggest that there is an optimal level of computer and internet use at school, substantially below a use intensity of several times a week.

Despite the extensive information on family and school background that we can control for, the PISA study still provides only observational data, where the availability and use of computers is not randomly divided between a treatment group that has computer access and a control group that does not have computer access. Therefore, in contrast to randomized experimental evidence, our evidence has to be interpreted cautiously in terms of descriptive conditional correlations, which do not necessarily allow for causal inferences because they may also reflect effects of other, unobservable characteristics. Still, the application shows that the multivariate analysis can go substantially beyond bivariate correlations in terms of detecting underlying relationships by disentangling these relationships from other observable influences. The results illustrate that accounting for other observable influence factors - i.e., comparing students who are equal in terms of other observable characteristics - can already yield results that are perfectly opposite to bivariate patterns. 
The remainder of the paper is structured as follows. Section 2 briefly describes previous research on the impact of computers and presents possible hypotheses on the impact of computerized learning and instruction on students' educational achievement. Section 3 introduces the database, the identification problem and the empirical model employed. Section 4 presents the results in terms of computer availability and use at home and at school. Section 5 concludes.

\section{Literature and Hypotheses}

\subsection{Research on the Economic and Educational Impact of Computers}

Using a computer may affect economic outcomes in at least two ways. First, computer skills knowing how to use a computer - may have direct effects on productivity and wages. Second, computers can be used as means for learning other skills, such as math, reading and science, which in turn may give rise to positive labor-market outcomes.

An increasing literature analyzes the first effect, the direct impact of computer skills on the labor market. In a seminal paper, Krueger (1993) found that computer use by workers is related to an expected wage that is approximately 10 to 15 percent higher in cross-sectional data. However, DiNardo and Pischke (1997) cast doubt that this finding reflects true returns to computer skills, as similar wage differentials can be found for the use of such devices as telephones and pencils. Using matched employer-employee panel data to identify the causal effect of computer skills on wages, Entorf, Gollac and Kramarz (1999) show that the crosssectional wage differential in favor of computer users is nearly entirely due to a selection bias of high-skilled workers into computer-using employments.

Recently, Borghans and ter Weel (2004) replicate the finding that the ability to effectively use a computer has no substantial impact on wages. At the same time, they show that math and writing abilities do yield significant returns on the labor market. Thus, they suggest that math and writing can be regarded as basic productive skills, while computer skills cannot.

Given that computer skills do not seem to have direct returns on the labor market, but more basic skills do, the possible impact of computers on learning skills such as math, writing, reading and science is an interesting topic. The existing evidence focuses on the effect of classroom computers on student achievement, showing mixed results at best. Reviews of observational studies such as Cuban (1993), Oppenheimer (1997) and Kirkpatrick and Cuban (1998) tend towards a negative assessment of the potential of using computers for instructional purposes in classrooms to improve students’ educational achievement. 
Wenglinsky (1998) and Angrist and Lavy (2002) even report negative effects of computer use in schools on some student achievement measures. The quasi-experimental study of Angrist and Lavy (2002) finds that the introduction of computer-aided instruction in Israeli schools exerted a statistically significant negative effect on the math achievement of fourthgrade students and a negative but statistically insignificant effect on student achievement in other subjects and higher grades. Recent studies by Borman and Rachuba (2001) and Rouse and Krueger (2004) analyze randomized experiments of computerized reading instruction, finding that noteworthy impacts of computerized instruction can be ruled out.

Thus, the evidence so far does not suggest that computers have a substantial impact on the economic and educational outcome of individuals, neither in terms of worker wages nor in terms of student learning. Despite numerous claims by politicians and software vendors to the contrary, the evidence so far suggests that computer use in schools does not seem to contribute substantially to students' learning of basic skills such as math or reading.

\subsection{Hypotheses on the Impact of Computers on Student Achievement}

At the most basic level, there are both hypotheses suggesting that computers may further student learning and hypotheses suggesting that computers may hinder student learning. Therefore, the expected net effect is equivocal - ultimately being an empirical question - and may depend on factors supporting either the positive or the negative effects.

The positive hypotheses run down to the point that everything else equal, computers constitute an input in students' learning process that should help produce better learning output. Computer use can enhance learning by making education less dependent on differing teacher quality and by making education available at home throughout the day. Using the computer to employ educational software can positively infer knowledge to students. Furthermore, internet access can help students exploit enormous information possibilities for schooling purposes and increase learning through communication.

A first set of negative hypotheses builds on the idea that, actually, everything else is not equal. Computerized instruction induces reallocations, substituting alternative, possibly more effective forms of instruction. Given a constant overall instruction time, this may decrease student achievement. Also, given that budgets are not perfectly elastic, the introduction of computerized instruction can result in a reallocation of funds in favor of computers, possibly substituting more effective instructional materials. 
A second set of negative hypotheses combines arguments that computers can distract from learning. This may be particularly salient at home, where computers may be used mainly to play computer games. This can keep students from doing homework and learning at home. Survey evidence suggests that computers at home indeed tend to be mainly used as toys (Wirth and Klieme 2003). Similarly, internet access could offer distraction by chat rooms or online games, reducing the time spent on doing homework or learning. Thus, the impact on student learning of the availability of computers and the internet will strongly depend on their specific uses.

A third set of negative hypotheses surrounds the argument that computer-aided instruction could restrict the creativity of children. Computerized programs tend to only allow acting in a predefined way with limited interactive possibilities. This might reduce students' abilities in terms of problem solving and creativity, thinking in predetermined schemes but not coming up with independent creative solutions by their own.

\section{Data and Empirical Identification}

\subsection{The PISA Data}

To estimate the relationship between computers and student learning empirically, we use the student-level dataset of the Programme for International Student Assessment (PISA), an international student achievement test of 15-year-old students conducted in 2000 by the Organisation for Economic Co-Operation and Development (OECD). The study tested student performance in reading, math and science in 32 developed and emerging countries, 28 of which are OECD countries. The OECD ensured a consistent and coherent study design and as much comparability as possible among the participating countries. The countries participating in the PISA 2000 study are: Australia, Austria, Belgium, Brazil, Canada, the Czech Republic, Denmark, Finland, France, Germany, Greece, Hungary, Iceland, Ireland, Italy, Japan, Korea, Latvia, Liechtenstein, ${ }^{1}$ Luxembourg, Mexico, the Netherlands, New Zealand, Norway, Poland, Portugal, the Russian Federation, Spain, Sweden, Switzerland, the United Kingdom and the United States. ${ }^{2}$

\footnotetext{
1 Liechtenstein was not included in our analysis due to lack of internationally comparable country-level data, e.g. on educational expenditure per student. Note also that there were only 32615 -year-old students in Liechtenstein in total, 314 of whom participated in PISA.

2 Adams and Wu (2002), OECD (2000, 2001, 2002) and the PISA webpage at www.pisa.oecd.org provide detailed information on the PISA study.
} 
PISA sampled a representative random sample of the population of 15-year-old students in each country. ${ }^{3}$ The PISA study tested the students with paper and pencil tests, which lasted two hours for each student. Using item response theory, the test results were transformed into test scores with an OECD mean of 500 points and an OECD standard deviation of 100 points.

In this paper, we use the student-level database constructed by Fuchs and Wößmann (2004), who provide more detailed information and notes on the specific database. They combine the test results with background information on students and schools from PISA background questionnaires answered by the specific students and schools tested in PISA. In addition to the rich PISA data at the student and school level, we also use some country-level data on the countries' GDP per capita, on their average educational expenditure per student in secondary education and on the existence of curriculum-based external exit exams.

In order to use all available information of the PISA test and estimate the maximum sample of students participating in the test, missing values in the student and school questionnaires were imputed (see Fuchs and Wößmann 2004 for details on the imputation method employed). Data imputation is preferable to dropping all observations with a missing value on at least one variable because it allows a much larger sample size, uses the available information on other explanatory variables for students with some missing information and because the estimator using only non-imputed data would yield biased results if the missing data follow a non-random pattern. To ensure consistency of estimation, the estimated regressions control for dummies on imputed data (see below).

In this paper, we focus on student performance in math and reading. Math performance is one of the "basic skills" that Borghans and ter Weel (2004) found to yield productive returns on the labor market. Similarly, other studies have shown before that math achievement is most strongly related to productivity (e.g., Bishop 1992). Also, math performance is generally viewed as being most readily comparable across countries. The sample size of our PISA database in math is 96,855 students from 31 countries. The PISA 2000 study had a special focus on the reading literacy of students, where the dataset covers 174,227 students from 31 countries. Thus, we conduct our estimations in math and reading. Science results, for which we find a pattern very similar to the other two subjects, are not reported here. ${ }^{4}$

3 Most PISA countries employed a two-stage stratified sampling technique. The first stage drew a (usually stratified) random sample of schools in which 15-year-old students were enrolled, yielding a minimum sample of 150 schools per country. The second stage randomly sampled 35 of the 15-year-old students in each of these schools, with each 15-year-old student in a school having equal probability of selection. Within each country, this sampling procedure typically led to a sample of between 4,500 and 10,000 tested students.

$4 \quad$ The specific science results are available from the authors on request. 
Table 1 presents descriptive statistics on the data on computer availability and use at home and at school that we employ in this paper. ${ }^{5}$ The table also reports the share of missing and thus imputed data for each variable. All data on computers at home stem from the student background questionnaire. In terms of computer availability, students report how many computers they have at home. We use two dummies on this variable, the first one reporting whether there is one computer in a student's home, the second one reporting whether there are two or more computers in the home. More than half of the students in our sample have more than one computer in their home, $25 \%$ have one computer and $23 \%$ do not have a computer at home. Students also report whether they have internet access at home or not, which $43 \%$ of the students have. Students also report how often they read emails and webpages because they want to do it, using five answer categories: "never or hardly ever”, “a few times a year”, “about once a month", "several times a month" and "several times a week". We use two dummies on this in our estimations, one for students who never or hardly ever use emails and webpages (38\% in our sample) and one for students who use them several times a week (27\%), with the remaining students lying in between. A final information on computers at home is whether students have educational software at home, which $55 \%$ of the students have.

In terms of computer availability at school, school principals report in the school background questionnaire how much the learning at their school is hindered by not having enough computers for instruction. Four answer categories are given: “not at all”, "very little”, "to some extent" and "a lot". We use two dummies on this variable, one reporting whether lack of computers hinders learning a lot (12\% of the students) and the other whether lack of computers does not hinder learning at all (30\%), with the remaining students again lying in between. School principals also report the number of computers in their schools, as well as the number of computers with internet connection. We use both variables in terms of computers per student. The international mean is 0.126 computers per student at school (or roughly 8 students on a computer) and 0.067 computers with internet access per student at school (or roughly 15 students on an internet-connected computer). In terms of computer use at school, there is additional information in the student background questionnaires. Students report how often they use computers at their school, in five answer categories: "never or hardly ever”, “a few times a year”, “about once a month”, “several times a month” and

\footnotetext{
5 Descriptive statistics on the extensive control variables employed can be found in Fuchs and Wößmann (2004)
} 
Table 1: Descriptive Statistics on Achievement and Computers

\begin{tabular}{|c|c|c|c|c|}
\hline & Mean & Std. Dev. & Source & Imputed \\
\hline \multicolumn{5}{|l|}{ Test scores } \\
\hline Math & 496.1 & 102.6 & St & 0.000 \\
\hline Reading & 495.4 & 101.3 & St & 0.000 \\
\hline \multicolumn{5}{|l|}{ Computers at home } \\
\hline \multicolumn{5}{|l|}{ Computers at home } \\
\hline None & 0.229 & & St & 0.025 \\
\hline One & 0.247 & & St & 0.025 \\
\hline More than one & 0.524 & & St & 0.025 \\
\hline Internet access at home & 0.431 & & St & 0.024 \\
\hline \multicolumn{5}{|l|}{ Use of email and webpages } \\
\hline Never or hardly ever & 0.381 & & St & 0.036 \\
\hline Several times a week & 0.265 & & St & 0.036 \\
\hline Educational software at home & 0.552 & & St & 0.028 \\
\hline \multicolumn{5}{|l|}{ Computers at school } \\
\hline \multicolumn{5}{|l|}{ Computers at school } \\
\hline Strongly lacking & 0.115 & & Sc & 0.044 \\
\hline No lack at all & 0.304 & & Sc & 0.044 \\
\hline PCs per student & 0.126 & 0.385 & Sc & 0.116 \\
\hline \multicolumn{5}{|l|}{ Computer use at school } \\
\hline Never or hardly ever & 0.259 & & St & 0.036 \\
\hline Several times a week & 0.277 & & St & 0.036 \\
\hline PCs with internet access per student & 0.067 & 0.218 & Sc & 0.137 \\
\hline \multicolumn{5}{|l|}{ Internet use at school } \\
\hline Never or hardly ever & 0.485 & & St & 0.039 \\
\hline Several times a week & 0.152 & & St & 0.039 \\
\hline
\end{tabular}

Notes: Mean: International mean, based on non-imputed data for each variable, weighted by sampling probabilities. - Std. Dev.: International standard deviation (only for discrete variables). - Source: Data source and thus level of observation: $\mathrm{St}=$ student achievement test or student background questionnaire; $\mathrm{Sc}=$ school background questionnaire. - Imputed: Fraction of students with missing and thus imputed data, weighted by sampling probabilities. 
"several times a week". Again, we use the two extreme categories as dummies, where $26 \%$ of the students never or hardly ever use computers at school and 28\% use computers at school several times a week. Similarly, students also report how often they use the internet at their school, where $49 \%$ use it never or hardly ever and only $15 \%$ use it several times a week.

\subsection{The Identification Problem}

As has been shown in numerous studies, students with more advantaged family backgrounds, such as better-educated parents or parents with higher-paying jobs, generally tend to perform substantially better in terms of educational achievement (e.g., Wößmann 2004). This may be the case because of heritability or because parents with more educated backgrounds provide more inputs for their children's learning in terms of home instruction, motivation, educational resources and so on (cf. Behrman and Rosenzweig 2002; Sacerdote 2002; Plug and Vijverberg 2003). Students from more advantaged family backgrounds also tend to have more computers at home. Thus, having computers at home will proxy for the economic, social and educational environment at home at the same time as potentially having an own direct impact on students' learning. It follows that any bivariate correlation between computers and student achievement can well be a sign of other beneficial family-background effects rather than a sign of computers having an effect on student achievement. This is the essence of the problem of identifying effects of computer availability and using observational data, because the computer effects can easily be confounded by effects of other factors. If these other variables are omitted from the empirical estimation, they will bias the estimated effect of computers.

Therefore, in our estimations, we try to control for as many other observable familybackground effects as possible. In the PISA background questionnaires, we have a vast amount of information on each student's personal and family background, as well as on each school's resource endowment and organizational structure. By directly controlling for the economic, social and educational environment at home in a multivariate analysis, we can at least make sure that any estimated effect of computers will not be driven by these other observable characteristics.

The identification problem is very similar in the case of computers at schools, because schools which have more computers also tend to have more of other school resources. For this reason, we try to substantially control for other school characteristics such as their endowment with other resources and their institutional features. 
Still, both in the case of computers at home and computers at school, there will be further unobserved characteristics left for which we cannot control. If these remaining unobserved characteristics are correlated with the computer variables and if they are themselves related to student performance, this will bias our estimated coefficients on the computer variables. For example, in the case of data on computer use, the decision to use computers may not be random, but rather endogenously determined by students’ ability. If our control variables do not fully control for student ability and if this ability is related to measured student performance, our estimates on computer use may well reflect this ability bias in addition to any causal effect of computer use. Therefore, our best estimates still do not necessarily show the causal effect of the computer variables on student performance. Rather, the estimates have to be interpreted cautiously as descriptive conditional correlations, in the sense that they report the relationship between computers and student learning conditional on holding constant the other family-background and school features that we can observe. While this is substantially more informative than simple bivariate correlations, it is still not the kind of causal information that controlled experiments could provide.

\subsection{The Empirical Model}

Following the discussion of the identification problem, we estimate the following multivariate microeconometric education production function:

$$
\begin{aligned}
T_{i s}= & C_{i s} \beta_{1}+B_{i s} \beta_{2} \\
& +D_{i s}^{C} \beta_{3}+\left(D_{i s}^{C} C_{i s}\right) \beta_{4}+D_{i s}^{B} \beta_{5}+\left(D_{i s}^{B} B_{i s}\right) \beta_{6}+\varepsilon_{i s},
\end{aligned}
$$

where $T_{i s}$ is the achievement test score of student $i$ in school $s . C$ is the vector of computer variables, and $B$ is a vector of background data. In the most elaborate specification, this control vector includes 8 variables on student characteristics, 28 variables on family background, 12 variables on resource inputs and 12 variables on institutions, as enumerated in Table 2 (see Fuchs and Wößmann 2004 for details on these control variables). The parameter vectors $\beta_{1}$ to $\beta_{6}$ will be estimated in the regression. The inclusion of the imputation dummies $D$ and the structure of the error term $\varepsilon$ will be discussed below. Note that this specification of the international education production function restricts the effects to be the same in all countries, as well as at all levels (within schools, between schools and between countries). While it might be interesting to analyze the potential heterogeneity of certain effects between countries and between levels, this paper restricts itself to analyzing the international mean 
Table 2: Control Variables

\begin{tabular}{|c|c|c|c|}
\hline Student characteristics [8] & Family background [28] & Resource inputs [12] & Institutions [12] \\
\hline $\begin{array}{l}\text { - Gender } \\
\text { - Age } \\
\text { - Grade (6 dummies) }\end{array}$ & $\begin{array}{l}\text { - Parental education (5 dummies) } \\
\text { - Migration status of father, mother and } \\
\text { student (3 dummies) } \\
\text { - Family status (3 dummies) } \\
\text { - Parents' work status (3 dummies) } \\
\text { - Parental occupation (2 dummies) } \\
\text { - Number of books at home (6 dummies) } \\
\text { - School's community location } \\
\text { (5 dummies) } \\
\text { - GDP per capita of country }\end{array}$ & $\begin{array}{l}\text { - Class size in subject (instrumented } \\
\text { by school's student-teacher ratio) } \\
\text { - Educational expenditure per student } \\
\text { of country } \\
\text { - Instructional material (2 dummies) } \\
\text { - Teacher education (3 dummies) } \\
\text { - Instruction time } \\
\text { - Homework time in subject } \\
\text { ( } 2 \text { dummies) } \\
\text { - Parental support (2 dummies) }\end{array}$ & $\begin{array}{l}\text { - External exit exams } \\
\text { - Standardized tests } \\
\text { - School autonomy in determining course } \\
\text { content, choosing textbooks, formulating } \\
\text { school budget, deciding on budget allocations, } \\
\text { hiring teachers, firing teachers, establishing } \\
\text { teachers' starting salaries and establishing } \\
\text { teachers' salary increases (8 dummies) } \\
\text { - Public vs. private school management } \\
\text { - Share of government funding in school budget }\end{array}$ \\
\hline
\end{tabular}


effect of computer use on student achievement. ${ }^{6}$ Fuchs and Wößmann (2004) provide a more detailed discussion of this general specification of the estimation equation.

We test for the robustness of our results in two further specifications. First, following Dronkers and Robert (2003), we control for possible school composition effects by including school means of student gender and of all the 28 family-background variables reported in Table 2. In effect, this adds 29 additional school-level variables to the background vector $B$. By controlling for the socio-economic composition of a school, this specification is meant to account for possible biases due to the endogenous sorting of students into schools. Second, to account for potential omitted variables at the country level, we additionally include a whole set of country dummies in the estimation of equation (1). These country fixed effects control for unobserved country-specific heterogeneity in the level of student performance.

As discussed in the previous section, some of the data are imputed rather than original. Generally, data imputation introduces measurement error in the explanatory variables, which should make it more difficult to observe statistically significant effects. Still, to make sure that the results are not driven by imputed data, two vectors of dummy variables $D^{C}$ and $D^{B}$ are included as controls in the estimation. The $D$ vectors contain one dummy for each variable in the vectors $C$ and $B$ that takes the value of 1 for observations with missing and thus imputed data and 0 for observations with original data. The inclusion of the $D$ vectors as controls in the estimation allows the observations with missing data on each variable to have their own intercepts. Furthermore, the inclusion of the interaction terms between imputation dummies and data vectors, $D^{C} C$ and $D^{B} B$, allows them to also have their own slopes for the respective variables. These imputation controls for each variable with missing values ensure that the results are robust against possible biases arising from data imputation.

Owing to the complex data structure produced by the PISA survey design and the multilevel nature of the explanatory variables, the error term $\varepsilon$ of the regression has a non-trivial structure. Although we include a considerable amount of school-related variables, we cannot be sure that there are no omitted variables at the school level. Given the possible dependence of students within the same school, the use of school-level variables and the fact that schools

6 Wößmann (2003) compares this restricted specification to an alternative two-step specification, discussing advantages and drawbacks particularly in light of potential omitted country-level variables. He finds that the substantive results are virtually the same in the alternative specification and provides arguments favoring the specification employed here. Furthermore, Fuchs and Wößmann (2004) show that this estimation specification can account for more than $85 \%$ of the between-country variation in test scores in each subject. Therefore, the scope for obvious unobserved country-specific heterogeneity seems small. In the most elaborate specifications of this paper, we also control for country fixed effects. 
were the primary sampling unit (PSU) in PISA, there may be unobservable correlation among the error terms $\varepsilon_{i s}$ at the school level (cf. Moulton 1986 for this problem of hierarchical data structure). We correct for potential correlations of the error terms by imposing an adequate structure on the covariance matrix. Thus, we suppose the error term to have the following structure:

$$
\varepsilon_{i s}=\eta_{s}+v_{i}
$$

where $\eta_{s}$ is the school-level element of the error term and $v_{i}$ is the student-specific element of the error term. We use clustering-robust linear regressions (CRLR) to estimate standard errors that recognize this clustering of the student-level data within schools. The CRLR method relaxes the independence assumption and requires only that the observations be independent across the PSUs, i.e. across schools. To avoid inefficiency due to heteroscedasticity, CRLR imposes a clustered covariance structure on the covariance matrix, allowing within-school correlations of the error term. By allowing any given amount of correlation within the PSUs, CRLR yields consistent and efficient estimates when many observations share the same value on some but not all independent variables (cf. Deaton 1997; White 1984).

Finally, PISA used a stratified sampling design within each country, producing varying sampling probabilities for different students. To obtain nationally representative estimates from the stratified survey data at the within-country level, we employ weighted least squares (WLS) estimation using sampling probabilities as weights. WLS estimation ensures that the proportional contribution to the parameter estimates of each stratum in the sample is the same as would have been obtained in a complete census enumeration (DuMouchel and Duncan 1983; Wooldridge 2001). Furthermore, at the between-country level, our weights give equal weight to each of the 31 countries.

\section{Results}

This section reports and discusses the empirical results on the relationship between computers and student achievement. First, we look at the availability of computers at home and at school. Then, we look at the use of computers at home and at school. 


\subsection{Computer Availability}

\section{Computer Availability at Home}

Table 3a reports the results on the availability of computers at home and student performance in math, successively adding groups of control variables. Column I regresses math performance only on the two dummies of computer availability at home, without controlling for any other impact. Similar to the OECD’s (2001, p. 118) finding that a computer interest index is positively related to performance, computer availability at home is strongly and statistically significantly positively related to student performance. Students with one computer at home perform 22.7 achievement points (AP) better than students without a computer at home, and students with more than one computer at home perform another 6.7 AP better. To provide an impression of the size of this performance difference, it may be compared to the unconditional international mean difference between students attending $9^{\text {th }}$ grade and students attending $10^{\text {th }}$ grade. These two grades contain the most students in the PISA study and show a difference of 30.3 AP in math (33.2 AP in reading). Thus, the unconditional performance difference between students with several computers at home and students with no computers at home is approximately equal to a whole grade difference. ${ }^{7}$

The regression reported in column II adds control variables for student characteristics, including gender, age and grade, which makes the computer estimates decrease slightly, but remaining large and statistically significantly positive. In column III, the family-background controls, such as education and occupation of parents, immigration and family status, are added to the regression. Now, the coefficients on computer availability at home become small and statistically insignificantly different from zero. That is, the initial positive correlation between computer availability at home and student performance was simply driven by the fact that students from better economic, social and educational family backgrounds tend to have more computers at home. Holding the other family-background characteristics constant, computer availability is not related to math performance.

In column IV, control variables for schools' resource endowments are added to the regression. Once these are controlled for, computer availability at home is statistically significantly negatively related to student performance. The more computers there are in a student's home, the worse the student's math performance. This pattern of results gets even

$7 \quad$ As an alternative benchmark, when estimating the average unconditional performance difference per month between students of different age and extrapolating this to a performance difference per year of age, this is equal to $12.9 \mathrm{AP}$ in math (16.4 AP in reading). 
Table 3a: Computer Availability at Home and Student Performance in Math

\begin{tabular}{|c|c|c|c|c|c|c|c|}
\hline & $\mathrm{I}$ & II & III & IV & $\mathrm{V}$ & VI & VII \\
\hline \multicolumn{8}{|l|}{ Computers at home } \\
\hline One & $22.737^{* * *}(1.589)$ & $17.143^{* * *}(1.457)$ & $1.791(1.290)$ & $-2.103^{*}(1.216)$ & $-3.921^{* * *}(1.174)$ & $-5.580^{* * *}(1.121)$ & $-5.907^{* * *}(1.106)$ \\
\hline More than one & $29.452^{* * *}(1.604)$ & $21.693^{* * *}(1.492)$ & $-2.068(1.355)$ & $-6.576^{* * *}(1.266)$ & $-9.804^{* * *}(1.192)$ & $-12.118^{* * *}(1.125)$ & $-13.863^{* * *}(1.070)$ \\
\hline Student characteristics [8] & - & incl. & incl. & incl. & incl. & incl. & incl. \\
\hline Family background [28] & - & - & incl. & incl. & incl. & incl. & incl. \\
\hline Resource inputs [12] & - & - & - & incl. & incl. & incl. & incl. \\
\hline Institutions [12] & - & - & - & - & incl. & incl. & incl. \\
\hline School composition [29] & - & - & - & - & - & incl. & incl. \\
\hline Country dummies [30] & - & - & - & - & - & - & incl. \\
\hline$R^{2}$ & 0.03 & 0.14 & 0.26 & 0.31 & 0.33 & 0.37 & 0.39 \\
\hline Observations & 96,855 & 96,855 & 96,855 & 96,855 & 96,855 & 96,855 & 96,855 \\
\hline
\end{tabular}

Notes: Dependent variable: PISA international math test score. - I-II: WLS regressions. - III-VII: 2SLS regressions with class size instrumented by schools' student-teacher ratio. - Regressions weighted by students' sampling probabilities. - Clustering-robust standard errors (taking account of correlated error terms within schools) in parentheses. - Significance level (based on clustering-robust standard errors): ${ }^{* * *} 1$ percent. $-{ }^{*} 10$ percent. 
Table 3b: Computer Availability at Home and Student Performance in Reading

\begin{tabular}{|c|c|c|c|c|c|c|c|}
\hline & $\mathrm{I}$ & II & III & IV & V & VI & VII \\
\hline \multicolumn{8}{|l|}{ Computers at home } \\
\hline One & $22.011^{* * *}(1.298)$ & $17.047^{* * *}(1.165)$ & $3.783^{* * *}(1.016)$ & $-1.075(1.126)$ & $-4.227^{* * *}(1.026)$ & $-5.558^{* * *}(0.893)$ & $-6.551^{* * *}(0.817)$ \\
\hline More than one & $26.008^{* * *}(1.427)$ & $19.205^{* * *}(1.285)$ & $-1.786(1.184)$ & $-5.885^{* * *}(1.246)$ & $-10.381^{* * *}(1.055)$ & $-12.500^{* * *}(0.914)$ & $-15.606^{* * *}(0.819)$ \\
\hline Student characteristics [8] & - & incl. & incl. & incl. & incl. & incl. & incl. \\
\hline Family background [28] & - & - & incl. & incl. & incl. & incl. & incl. \\
\hline Resource inputs [12] & - & - & - & incl. & incl. & incl. & incl. \\
\hline Institutions [12] & - & - & - & - & incl. & incl. & incl. \\
\hline School composition [29] & - & - & - & - & - & incl. & incl. \\
\hline Country dummies [30] & - & - & - & - & - & - & incl. \\
\hline$R^{2}$ & 0.02 & 0.15 & 0.29 & 0.33 & 0.34 & 0.38 & 0.40 \\
\hline Observations & 174,227 & 174,227 & 174,227 & 174,227 & 174,227 & 174,227 & 174,227 \\
\hline
\end{tabular}

Notes: Dependent variable: PISA international reading test score. - I-II: WLS regressions. - III-VII: 2SLS regressions with class size instrumented by schools' student-teacher ratio. - Regressions weighted by students' sampling probabilities. - Clustering-robust standard errors (taking account of correlated error terms within schools) in parentheses. - Significance level (based on clustering-robust standard errors): ${ }^{* * *} 1$ percent. 
more pronounced when controls for institutional features of the schools are added in column V. Similarly, it stays unchanged when the schools' socio-economic composition is controlled for in column VI, as well as when country fixed effects are included in column VII. In this most elaborate specification, students with one computer at home perform statistically significantly 5.9 AP lower than students without a computer at home, and students with several computers at home perform another 8.0 AP worse.

Table 3b reports the same results for reading literacy. The pattern is the same as in math. An initial statistically significant and sizable positive correlation between computer availability at home and reading performance is turned around into a statistically significant and sizable negative one once student and family background as well as schools' resources and institutional features are controlled for.

\section{Computer Availability at School}

Tables 4a and 4b report equivalent estimations for the relationship between computer availability at school and student performance in math and reading. The initial correlations in column I suggest that students perform statistically significantly and sizably (40.7 AP in math and 36.5 AP in reading) worse in schools where computers are strongly lacking. There is no statistically significant performance difference between students in schools without any lack of computers and students in schools with little or some lack of computers. This pattern of results stays intact once student and family characteristics are controlled for in columns II and III. However, the picture starts to turn once measures of schools' resource endowments are added as controls. In math, there is no longer a statistically significant performance gap for students in schools where computers are strongly lacking, and students in schools without a lack of computers now actually show a statistically significant lower performance. The same pattern emerges in both subjects in the specifications that additionally control for schools' institutional features and socio-economic composition in columns V and VI. Once country fixed effects are added in column VII, none of the performance differences between students with different extents of computer availability at school is statistically significant. That is, the initial positive pattern on computer availability at school simply reflects that schools with better computer availability also feature other positive school characteristics. Once these are controlled for, computer availability at school is not related to student performance in math and reading.

Column VIII adds the variable on the number of computers per student at the school to the most elaborate specification. This variable is also not statistically significantly related to 
Table 4a: Computer Availability at School and Student Performance in Math

\begin{tabular}{|c|c|c|c|c|c|c|c|c|}
\hline & $\mathrm{I}$ & II & III & IV & $\mathrm{V}$ & VI & VII & VIII \\
\hline \multicolumn{9}{|l|}{ Computers at school } \\
\hline Strongly lacking & $-40.717^{* * *}(3.600)$ & $-31.847^{* * *}(3.170)$ & $-15.611^{* * *}(2.466)$ & $-2.777(2.307)$ & $-1.568(2.133)$ & $-0.463(2.015)$ & $-1.592(1.870)$ & $-1.624(1.872)$ \\
\hline No lack at all & $-0.280(2.403)$ & $1.420(2.081)$ & $1.659(1.805)$ & $-4.395^{* *}(1.733)$ & $-6.053^{* * *}(1.640)$ & $-2.344^{*}(1.415)$ & $-1.314(1.236)$ & $-1.315(1.236)$ \\
\hline PCs per student & - & - & - & - & - & - & - & $-0.480(0.829)$ \\
\hline Student characteristics [8] & - & incl. & incl. & incl. & incl. & incl. & incl. & incl. \\
\hline Family background [28] & - & - & incl. & incl. & incl. & incl. & incl. & incl. \\
\hline Resource inputs [12] & - & - & - & incl. & incl. & incl. & incl. & incl. \\
\hline Institutions [12] & - & - & - & - & incl. & incl. & incl. & incl. \\
\hline School composition [29] & - & - & - & - & - & incl. & incl. & incl. \\
\hline Country dummies [30] & - & - & - & - & - & - & incl. & incl. \\
\hline$\overline{R^{2}}$ & 0.02 & 0.13 & 0.26 & 0.31 & 0.33 & 0.36 & 0.39 & 0.39 \\
\hline Observations & 96,855 & 96,855 & 96,855 & 96,855 & 96,855 & 96,855 & 96,855 & 96,855 \\
\hline
\end{tabular}

Notes: Dependent variable: PISA international math test score. - I-II: WLS regressions. - III-VIII: 2SLS regressions with class size instrumented by schools' student-teacher ratio. - Regressions weighted by students' sampling probabilities. - Clustering-robust standard errors (taking account of correlated error terms within schools) in parentheses. Significance level (based on clustering-robust standard errors): ${ }^{* * *} 1$ percent. $-{ }^{* *} 5$ percent. $-{ }^{*} 10$ percent. 
Table 4b: Computer Availability at School and Student Performance in Reading

\begin{tabular}{|c|c|c|c|c|c|c|c|c|}
\hline & I & II & III & IV & $\mathrm{V}$ & VI & VII & VIII \\
\hline \multicolumn{9}{|l|}{ Computers at school } \\
\hline Strongly lacking & $-36.456^{* * *}(3.285)$ & $-27.819^{* * *}(2.834)$ & $-14.862^{* * *}(2.155)$ & $-5.213^{* *}(2.285)$ & $-2.868(2.069)$ & $-1.845(1.806)$ & $-1.778(1.631)$ & $-1.812(1.634)$ \\
\hline No lack at all & $-0.092(2.310)$ & $1.010(1.953)$ & $0.407(1.592)$ & $-5.076^{* * *}(1.693)$ & $-6.234^{* * *}(1.564)$ & $-2.430^{*}(1.306)$ & $-1.184(1.108)$ & $-1.179(1.108)$ \\
\hline PCs per student & - & - & - & - & - & - & - & $-0.584(0.744)$ \\
\hline Student characteristics [8] & - & incl. & incl. & incl. & incl. & incl. & incl. & incl. \\
\hline Family background [28] & - & - & incl. & incl. & incl. & incl. & incl. & incl. \\
\hline Resource inputs [12] & - & - & - & incl. & incl. & incl. & incl. & incl. \\
\hline Institutions [12] & - & - & - & - & incl. & incl. & incl. & incl. \\
\hline School composition [29] & - & - & - & - & - & incl. & incl. & incl. \\
\hline Country dummies [30] & - & - & - & - & - & - & incl. & incl. \\
\hline$\overline{R^{2}}$ & 0.01 & 0.15 & 0.29 & 0.32 & 0.34 & 0.38 & 0.40 & 0.40 \\
\hline Observations & 174,227 & 174,227 & 174,227 & 174,227 & 174,227 & 174,227 & 174,227 & 174,227 \\
\hline
\end{tabular}

Notes: Dependent variable: PISA international reading test score. - I-II: WLS regressions. - III-VIII: 2SLS regressions with class size instrumented by schools’ student-teacher ratio. - Regressions weighted by students' sampling probabilities. - Clustering-robust standard errors (taking account of correlated error terms within schools) in parentheses. Significance level (based on clustering-robust standard errors): ${ }^{* * *} 1$ percent. $-{ }^{* *} 5$ percent. $-{ }^{*} 10$ percent. 
student performance. The statistical insignificance of this variable is already given in a bivariate correlation, and it remains throughout the other specifications that add more control variables.

In sum, the results cast strong doubt that the mere availability of computers at home and at school does a lot to advance students' educational performance. While bivariate results would suggest that there is a positive relationship in both cases, these results are spurious. Once other features of student, family and school background are held constant, computer availability at home shows a strong statistically significant negative relationship to math and reading performance, and computer availability at school is unrelated to performance.

The pattern of which particular additional group of control variables brings about the change in results is telling. In the case of computer availability at home, the first big change enters when family-background characteristics are controlled for. That is, the strongest bias is due to the fact that computer availability at home proxies for the economic, social and educational background of the students' families. The fact that the negative pattern becomes more pronounced once schools' resources, institutions and composition are controlled for suggests that computer availability at home is also positively correlated with positive school characteristics. In the case of computer availability at school, the result pattern changes only once schools' resource endowments are controlled for. That is, in this case the bias is mainly due to the fact that computer availability at school proxies for other resource endowments of the schools, rather than for family background.

\subsection{Computer Use}

The regressions reported in Tables $5 \mathrm{a}$ and $5 \mathrm{~b}$ extent the results beyond the mere availability of computers at home or at school. All results are based on the most elaborate specification, which controls for student characteristics, family background, resource inputs, institutions, school composition and country fixed effects. The regression in column I simply combines the availability of computers at home and at school, showing that the previous results are robust to their joint entrance in the regression. The following regressions add measures of computer use at home and at school to this specification.

\section{Computer Use at Home}

There are three proxy measures for the kind of computer use at home in the PISA questionnaires, which are added to the regression in column II. The first thing to note is that 
Table 5a: Computer Use at Home and at School and Student Performance in Math

\begin{tabular}{|c|c|c|c|c|}
\hline & I & II & III & IV \\
\hline \multicolumn{5}{|l|}{ Computers at home } \\
\hline One & $-5.895^{* * *}(1.106)$ & $-6.981^{* * *}(1.103)$ & - & $-7.086^{* * *}(1.104)$ \\
\hline More than one & $13.843^{* * *}(1.069)$ & $-16.359^{* * *}(1.080)$ & - & $-16.164^{* * *}(1.078)$ \\
\hline Internet access & - & $4.859^{* * *}(0.955)$ & - & $4.590^{* * *}(0.935)$ \\
\hline \multicolumn{5}{|l|}{ Use of email and webpages } \\
\hline Never or hardly ever & - & $-7.614^{* * *}(0.864)$ & - & $-7.003^{* * *}(0.868)$ \\
\hline Several times a week & - & $4.055^{* * *}(0.884)$ & - & $6.301^{* * *}(0.914)$ \\
\hline Educational software & - & $2.116^{* * *}(0.815)$ & - & $1.788^{* *}(0.806)$ \\
\hline \multicolumn{5}{|l|}{ Computers at school } \\
\hline Strongly lacking & $-1.803(1.864)$ & - & $-0.871(1.887)$ & $-1.093(1.882)$ \\
\hline No lack at all & $-1.218(1.233)$ & - & $-1.357(1.221)$ & $-1.259(1.209)$ \\
\hline PCs per student & - & - & 1.415 (2.073) & $1.575(2.066)$ \\
\hline \multicolumn{5}{|l|}{ Computer use at school } \\
\hline Never or hardly ever & - & - & $-1.938^{*}(1.039)$ & $-2.323^{* *}(1.035)$ \\
\hline Several times a week & - & - & $-6.321^{* * *}(1.098)$ & $-6.075^{* * *}(1.089)$ \\
\hline PCs with internet access per studer & ent & - & $-4.134(3.874)$ & $-4.436(3.914)$ \\
\hline \multicolumn{5}{|l|}{ Internet use at school } \\
\hline Never or hardly ever & - & - & $-3.741^{* * *}(1.024)$ & $-2.079^{* *}(1.023)$ \\
\hline Several times a week & - & - & $-6.694^{* * *}(1.294)$ & $-9.224^{* * *}(1.336)$ \\
\hline Student characteristics [8] & incl. & incl. & incl. & incl. \\
\hline Family background [28] & incl. & incl. & incl. & incl. \\
\hline Resource inputs [12] & incl. & incl. & incl. & incl. \\
\hline Institutions [12] & incl. & incl. & incl. & incl. \\
\hline School composition [29] & incl. & incl. & incl. & incl. \\
\hline Country dummies [30] & incl. & incl. & incl. & incl. \\
\hline$\overline{R^{2}}$ & 0.40 & 0.40 & 0.40 & 0.40 \\
\hline Observations & 96,855 & 96,855 & 96,855 & 96,855 \\
\hline
\end{tabular}

Notes: Dependent variable: PISA international math test score. - 2SLS regressions with class size instrumented by schools' student-teacher ratio. - Regressions weighted by students' sampling probabilities. - Clustering-robust standard errors (taking account of correlated error terms within schools) in parentheses. - Significance level (based on clustering-robust standard errors): ${ }^{* * *} 1$ percent. $-{ }^{* *} 5$ percent. $-{ }^{*} 10$ percent. 
Table 5b: Computer Use at Home and at School and Student Performance in Reading

\begin{tabular}{|c|c|c|c|c|}
\hline & I & II & III & IV \\
\hline \multicolumn{5}{|l|}{ Computers at home } \\
\hline One & $-6.603^{* * *}(0.815)$ & $-7.547^{* * *}(0.815)$ & - & $-7.631^{* * *}(0.811)$ \\
\hline More than one & $-15.697^{* * *}(0.820)$ & $-17.995^{* * *}(0.836)$ & - & $-17.932^{* * *}(0.834)$ \\
\hline Internet access & - & $4.808^{* * *}(0.705)$ & - & $4.450^{* * *}(0.697)$ \\
\hline \multicolumn{5}{|l|}{ Use of email and webpages } \\
\hline Never or hardly ever & - & $-6.403^{* * *}(0.665)$ & - & $-6.183^{* * *}(0.665)$ \\
\hline Several times a week & - & $5.916^{* * *}(0.668)$ & - & $8.703^{* * *}(0.681)$ \\
\hline Educational software & - & $0.088(0.603)$ & - & $-0.278(0.596)$ \\
\hline \multicolumn{5}{|l|}{ Computers at school } \\
\hline Strongly lacking & $-1.960(1.622)$ & - & $-1.166(1.642)$ & $-1.363(1.626)$ \\
\hline No lack at all & $-1.149(1.102)$ & - & $-1.216(1.092)$ & $-1.152(1.075)$ \\
\hline PCs per student & - & - & $-1.798(2.537)$ & $-1.540(2.398)$ \\
\hline \multicolumn{5}{|l|}{ Computer use at school } \\
\hline Never or hardly ever & - & - & $-0.528(0.812)$ & $-0.887(0.806)$ \\
\hline Several times a week & - & - & $-5.067^{* * *}(0.851)$ & $-4.934^{* * *}(0.843)$ \\
\hline PCs with internet access per stude & dent & - & $2.202(4.790)$ & $1.688(4.648)$ \\
\hline \multicolumn{5}{|l|}{ Internet use at school } \\
\hline Never or hardly ever & - & - & $-2.986^{* * *}(0.809)$ & $-1.519^{*}(0.798)$ \\
\hline Several times a week & - & - & $-9.552^{* * *}(1.021)$ & $-12.577^{* * *}(1.037)$ \\
\hline Student characteristics [8] & incl. & incl. & incl. & incl. \\
\hline Family background [28] & incl. & incl. & incl. & incl. \\
\hline Resource inputs [12] & incl. & incl. & incl. & incl. \\
\hline Institutions [12] & incl. & incl. & incl. & incl. \\
\hline School composition [29] & incl. & incl. & incl. & incl. \\
\hline Country dummies [30] & incl. & incl. & incl. & incl. \\
\hline$\overline{R^{2}}$ & 0.40 & 0.40 & 0.40 & 0.41 \\
\hline Observations & 174,227 & 174,227 & 174,227 & 174,227 \\
\hline
\end{tabular}

Notes: Dependent variable: PISA international reading test score. - 2SLS regressions with class size instrumented by schools' student-teacher ratio. - Regressions weighted by students' sampling probabilities. Clustering-robust standard errors (taking account of correlated error terms within schools) in parentheses. - Significance level (based on clustering-robust standard errors): ${ }^{* * *} 1$ percent. $-{ }^{*} 10$ percent. 
the negative results on computer availability at home remain unchanged once the computeruse variables are entered.

Only part of the students who have computers at home also have internet access at home. Having internet access can already hint towards possible alternative uses of computers. Holding all other influences constant, the performance of students with internet access at home is statistically significantly better in math and reading than the performance of students without internet access at home. Additionally, student performance in both math and reading increases with the frequency of the use of email and webpages by the students. Students who never or hardly ever read emails and webpages perform statistically significantly worse than students who use them between a few times a year and several times a month, and students who use emails and webpages several times a week perform statistically significantly better. Finally, students that have educational software at home perform statistically significantly better in math. However, having educational software at home is not statistically significantly related to student performance in reading literacy.

We suggest two possible interpretations of these positive results of computer use at home. First, they may simply reflect that more able students tend to be more likely to get internet access and educational software at home and to use emails and webpages regularly. While this interpretation is possible, it is not obvious that this kind of ability bias is the main story here. It might as well be the case that parents tend to be more likely to provide their children with internet access and educational software if they want to make up for relatively low ability. Particularly in the case of educational software, parents may tend to buy this equipment for low-ability rather than high-ability students.

Alternatively, if ability biases do not account for all of the observed performance differences by computer use, the results may suggest that using computers for productive purposes at home indeed furthers students' educational performance. In this interpretation, the effect of computers at home on student achievement depends on the specific uses to which the computers are taken. The mere availability of computers at home may in the first instance serve children as devises to play computer games. This distracts them from learning, and thus affects their educational performance negatively. But if the computers are instead used for other means than gaming, namely for communicating by email, accessing information on the internet and using educational software, this may compensate, at least partly, for the negative effects induced by computer availability at home and help to advance children's knowledge in math and reading. 


\section{Computer Use at School}

Column III of Tables 5a and $5 \mathrm{~b}$ reports the coefficient estimates on several measures of computer availability and use at school. Again, adding the computer-use measures does not change the results on computer availability at school. The mere availability of computers with internet connection at school is also not statistically significantly related to student performance.

In terms of computer use at school, on the one hand, students who never or hardly ever use computers at school perform slightly lower than students who use computers at school between a few times a year and several times a month. This performance difference is statistically significant in math, but not in reading. On the other hand, students who use computers at school several times a week perform sizably and statistically significantly worse in both math and reading. A very similar pattern of results is found in the case of internet use at school. In both math and reading, students reporting no internet use at school perform statistically significantly lower than students of medium internet use at school, while students who use the internet at school several times a week even perform statistically significantly worse than both other groups. That is, both in the case of computer use at school and of internet use at school, the relationship is shaped as an inverted $\mathrm{U}$, with student achievement initially increasing and subsequently decreasing with the intensity of computer and internet use at school. The regression in column IV shows that all previous results on computer availability and use at home and at school are also robust to entering all computer variables at once.

Again, we suggest two possible patterns of interpretation for the results on computer use at school. First, there may again be an ability bias. In this case, it seems reasonable to expect that teachers would not want to use computers with very low-ability students, but only with students who are reasonably capable to use them. This may explain the fact that students who never or hardly ever use computers or the internet at school perform somewhat lower, which then would simply reflect that they are low-ability students. It seems less likely that such an ability effect can also account for the substantially lower performance of students who use computers and the internet at school several times a week. This latter finding might instead be explained by a true negative effect of excessive computer use at school. As argued above, computerized instruction may substitute alternative, more effective forms of instruction, and it may also harm the creativity of children's learning. This result would then be in line with 
Angrist and Lavy's (2002) quasi-experimental finding that in some cases, computer use at schools can have negative effects on students’ educational achievement.

There is also a second interpretation of the pattern of results, which does not consider ability biases. In this interpretation, the inverted U-shape of the relationship between computer and internet use at school and student performance may be due to a true causal effect of computer and internet use. In this case, some computerized instruction would be beneficial for student learning, constituting a valuable input in the students' learning process. Only at higher intensities of computer and internet use at school would the negative effects of computer and internet use set in, in terms of crowding out more effective methods of teaching and of hindering student creativity. Thus, there may be an optimal level of computer and internet use at school, with student learning initially increasing and subsequently decreasing with the intensity of computer and internet use. The presented results suggest that this optimal level may be pretty low, though, somewhere between using computers and the internet at school "a few times a year" and "several times a month", as students in these categories perform better than students in the categories of both "never or hardly ever" and "several times a week”.

\section{Conclusions}

This paper has found that despite bivariate correlations that show a positive relationship, once family background and school characteristics are extensively controlled for, the mere availability of computers at home is negatively related to student performance in math and reading, and the availability of computers at school is unrelated to student performance. By contrast, student performance is positively related to the use of computers at home for accessing emails and webpages and to the availability of educational software at home. Finally, student performance shows an inverted U-shaped relationship with the extent of computer and internet use at school, rising with some use but falling again with a use of several times a week.

Despite the extensive use of control variables, the analysis has still been descriptive rather than causal. For a thorough analysis of causal effects of computers on student performance, we have to be sure that the variation in computer availability and use on which the analysis is based is truly exogenous to the model. For analyses based on observational rather than experimental data, this is always a somewhat strong assumption. However, given our extensive controlling for student, family and school background effects, the descriptive results 
that we obtain give a clearer picture of the relationship between computers and student performance than mere bivariate analyses. Actually, the diametrically opposite difference between our bivariate and multivariate results for the availability of computers at home shows that the simple bivariate picture is clearly not based on exogenous variation in computer availability, and is therefore a far cry from depicting any causal effect of computer availability. Rather than the statistically significant and large positive bivariate correlation between computer availability and student performance, once we control extensively for family background we find a statistically significant and large negative relationship between the two. This is still a descriptive finding, but one which we think should come much closer to any causal effect than the often presented bivariate relationship.

Our results on computer availability and use at school corroborate previous work on school computers such as Angrist and Lavy (2002) and Rouse and Krueger (2004), who also find disappointing results in terms of effects on students' educational performance. Our results on computer availability and use at home extends this evidence, illustrating that there is also a negative relationship between home computer availability and student achievement, but a positive relationship between home computer use for internet communication and educational software. Similarly, our results on internet use at school complement the previous evidence on computer use at school.

Having a computer at home and using it at school will almost certainly raise some computer skills. What our results suggest is only that this may come at the expense of other skills. However, the results in Borghans and ter Weel (2004) show that these other (math and writing) skills are the ones that yield significant labor-market returns, not the computer skills.

Our results also cast strong doubt on the possibility of giving a causal interpretation to bivariate results for other variables. For example, the OECD (2001) reports bivariate correlations of student performance with such features as reading interest, motivation, engagement and different teaching techniques. Our results suggest that any such finding may well be spurious, being driven by other important factors. In this sense, our exercise provides an illustration of the need for, at least, multivariate analysis. 


\section{References}

Adams, Ray, Margaret Wu (eds.) (2002). PISA 2000 Technical Report. Paris: Organisation for Economic Co-operation and Development (OECD).

Angrist, Joshua, Victor Lavy (2002). New Evidence on Classroom Computers and Pupil Learning. Economic Journal 112 (482): 735-765.

Behrman, Jere R., Mark R. Rosenzweig (2002). Does Increasing Women’s Schooling Raise the Schooling of the Next Generation? American Economic Review 92 (1): 323-334.

Bishop, John H. (1992). The Impact of Academic Competencies on Wages, Unemployment, and Job Performance. Carnegie-Rochester Conference Series on Public Policy 37: 127194.

Borghans, Lex, Bas ter Weel (2004). Are Computer Skills the New Basic Skills? The Returns to Computer, Writing and Math Skills in Britain. Labour Economics 11 (1): 85-98.

Borman, Geoffrey D., Laura T. Rachuba (2001). Evaluation of the Scientific Learning Corporation's FastForWord Computer-Based Training Program in the Baltimore City Public Schools. Report Prepared for the Abell Foundation.

Cuban, Larry (1993). Computers Meet Classroom: Classroom Wins. Teachers College Record 95 (2): 185-210.

Deaton, Angus (1997). The Analysis of Household Surveys: A Microeconometric Approach to Development Policy. Baltimore: The Johns Hopkins University Press.

DiNardo, John E., Jörn-Steffen Pischke (1997). The Returns to Computer Use Revisited: Have Pencils Changed the Wage Structure Too? Quarterly Journal of Economics 112 (1): 291-303.

Dronkers, Jaap, Péter Robert (2003). The Effectiveness of Public and Private Schools from a Comparative Perspective. EUI Working Paper SPS 2003-13. Florence: European University Institute.

DuMouchel, William H., Greg J. Duncan (1983). Using Sample Survey Weights in Multiple Regression Analyses of Stratified Samples. Journal of the American Statistical Association 78 (383): 535-543.

Entorf, Horst, Michel Gollac, Francis Kramarz (1999). New Technologies, Wages, and Worker Selection. Journal of Labor Economics 17 (3): 464-491.

Fuchs, Thomas, Ludger Wößmann (2004). What Accounts for International Differences in Student Performance? A Re-examination using PISA Data. CESifo Working Paper (in press). Munich: CESifo.

Kirkpatrick, Heather, Larry Cuban (1998). Computers Make Kids Smarter - Right? Technos Quarterly 7 (2). [http://www.technos.net/tq_07/2cuban.htm]

Krueger, Alan B. (1993). How Computers Have Changed the Wage Structure: Evidence from Microdata, 1984-1989. Quarterly Journal of Economics 108 (1): 33-60.

Lindbeck, Assar, Dennis Snower (2000). Multitask Learning and the Reorganization of Work: From Tayloristic to Holistic Organization. Journal of Labor Economics 18 (3): 353-376.

Moulton, Brent R. (1986). Random Group Effects and the Precision of Regression Estimates. Journal of Econometrics 32 (3): 385-397.

Oppenheimer, Todd (1997). The Computer Delusion. Atlantic Monthly 280 (1), July. 
Organisation for Economic Co-operation and Development (OECD) (2000). Measuring Student Knowledge and Skills: The PISA 2000 Assessment of Reading, Mathematical and Scientific Literacy. Paris: OECD.

Organisation for Economic Co-operation and Development (OECD) (2001). Knowledge and Skills for Life: First Results from the OECD Programme for International Student Assessment (PISA) 2000. Paris: OECD.

Organisation for Economic Co-operation and Development (OECD) (2002). Manual for the PISA 2000 Database. Paris: OECD.

Plug, Erik, Wim Vijverberg (2003). Schooling, Family Background, and Adoption: Is It Nature or Is It Nurture? Journal of Political Economy 111 (3): 611-641.

Rouse, Cecilia E., Alan B. Krueger, with Lisa Markman (2004). Putting Computerized Instruction to the Test: A Randomized Evaluation of a "Scientifically-based" Reading Program. NBER Working Paper 10315. Cambridge, MA: National Bureau of Economic Research.

Sacerdote, Bruce (2002). The Nature and Nurture of Economic Outcomes. American Economic Review, Papers and Proceedings 92 (2): 344-348.

Wenglinsky, Harold (1998). Does It Compute? The Relationship Between Educational Technology and Achievement in Mathematics. Princeton, NJ: Policy Information Center, Research Division, Educational Testing Service.

White, Halbert (1984). Asymptotic Theory for Econometricians. Orlando: Academic Press.

Wirth, Joachim, Eckhard Klieme (2003). Computernutzung. In: Deutsches PISA-Konsortium (ed.), PISA 2000: Ein differenzierter Blick auf die Länder der Bundesrepublik Deutschland: 195-209. Opladen: Leske + Budrich.

Wooldridge, Jeffrey M. (2001). Asymptotic Properties of Weighted M-Estimators for Standard Stratified Samples. Econometric Theory 17 (2): 451-470.

Wößmann, Ludger (2003). Schooling Resources, Educational Institutions, and Student Performance: The International Evidence. Oxford Bulletin of Economics and Statistics 65 (2): 117-170.

Wößmann, Ludger (2004). How Equal Are Educational Opportunities? Family Background and Student Achievement in Europe and the United States. CESifo Working Paper 1162. Munich: CESifo. 


\section{CESifo Working Paper Series}

(for full list see www.cesifo.de)

1261 Joop Hartog, Hans van Ophem, and Simona Maria Bajdechi, How Risky is Investment in Human Capital?, August 2004

1262 Thomas Eichner and Rüdiger Pethig, Efficient Nonanthropocentric Nature Protection, August 2004

1263 David-Jan Jansen and Jakob de Haan, Look Who's Talking: ECB Communication during the First Years of EMU, August 2004

1264 David F. Bradford, The X Tax in the World Economy, August 2004

1265 Hans-Werner Sinn, Migration, Social Standards and Replacement Incomes. How to Protect Low-income Workers in the Industrialized Countries against the Forces of Globalization and Market Integration, August 2004

1266 Wolfgang Leininger, Fending off one Means Fending off all: Evolutionary Stability in Submodular Games, August 2004

1267 Antoine Bommier and Bertrand Villeneuve, Risk Aversion and the Value of Risk to Life, September 2004

1268 Harrie A. A. Verbon and Lex Meijdam, Too Many Migrants, Too Few Services: A Model of Decision-making on Immigration and Integration with Cultural Distance, September 2004

1269 Thomas Eichner and Rüdiger Pethig, Economic Land Use, Ecosystem Services and Microfounded Species Dynamics, September 2004

1270 Federico Revelli, Performance Rating and Yardstick Competition in Social Service Provision, September 2004

1271 Gerhard O. Orosel and Klaus G. Zauner, Vertical Product Differentiation When Quality is Unobservable to Buyers, September 2004

1272 Christoph Böhringer, Stefan Boeters, and Michael Feil, Taxation and Unemployment: An Applied General Equilibrium Approach, September 2004

1273 Assaf Razin and Efraim Sadka, Welfare Migration: Is the Net Fiscal Burden a Good Measure of its Economics Impact on the Welfare of the Native-Born Population?, September 2004

1274 Tomer Blumkin and Volker Grossmann, Ideological Polarization, Sticky Information, and Policy Reforms, September 2004 
1275 Katherine Baicker and Nora Gordon, The Effect of Mandated State Education Spending on Total Local Resources, September 2004

1276 Gabriel J. Felbermayr and Wilhelm Kohler, Exploring the Intensive and Extensive Margins of World Trade, September 2004

1277 John Burbidge, Katherine Cuff and John Leach, Capital Tax Competition with Heterogeneous Firms and Agglomeration Effects, September 2004

1278 Joern-Steffen Pischke, Labor Market Institutions, Wages and Investment, September 2004

1279 Josef Falkinger and Volker Grossmann, Institutions and Development: The Interaction between Trade Regime and Political System, September 2004

1280 Paolo Surico, Inflation Targeting and Nonlinear Policy Rules: The Case of Asymmetric Preferences, September 2004

1281 Ayal Kimhi, Growth, Inequality and Labor Markets in LDCs: A Survey, September 2004

1282 Robert Dur and Amihai Glazer, Optimal Incentive Contracts for a Worker who Envies his Boss, September 2004

1283 Klaus Abberger, Nonparametric Regression and the Detection of Turning Points in the Ifo Business Climate, September 2004

1284 Werner Güth and Rupert Sausgruber, Tax Morale and Optimal Taxation, September 2004

1285 Luis H. R. Alvarez and Erkki Koskela, Does Risk Aversion Accelerate Optimal Forest Rotation under Uncertainty?, September 2004

1286 Giorgio Brunello and Maria De Paola, Market Failures and the Under-Provision of Training, September 2004

1287 Sanjeev Goyal, Marco van der Leij and José Luis Moraga-González, Economics: An Emerging Small World?, September 2004

1288 Sandro Maffei, Nikolai Raabe and Heinrich W. Ursprung, Political Repression and Child Labor: Theory and Empirical Evidence, September 2004

1289 Georg Götz and Klaus Gugler, Market Concentration and Product Variety under Spatial Competition: Evidence from Retail Gasoline, September 2004

1290 Jonathan Temple and Ludger Wößmann, Dualism and Cross-Country Growth Regressions, September 2004

1291 Ravi Kanbur, Jukka Pirttilä and Matti Tuomala, Non-Welfarist Optimal Taxation and Behavioral Public Economics, October 2004 
1292 Maarten C. W. Janssen, José Luis Moraga-González and Matthijs R. Wildenbeest, Consumer Search and Oligopolistic Pricing: An Empirical Investigation, October 2004

1293 Kira Börner and Christa Hainz, The Political Economy of Corruption and the Role of Financial Institutions, October 2004

1294 Christoph A. Schaltegger and Lars P. Feld, Do Large Cabinets Favor Large Governments? Evidence from Swiss Sub-Federal Jurisdictions, October 2004

1295 Marc-Andreas Mündler, The Existence of Informationally Efficient Markets When Individuals Are Rational, October 2004

1296 Hendrik Jürges, Wolfram F. Richter and Kerstin Schneider, Teacher Quality and Incentives: Theoretical and Empirical Effects of Standards on Teacher Quality, October 2004

1297 David S. Evans and Michael Salinger, An Empirical Analysis of Bundling and Tying: Over-the-Counter Pain Relief and Cold Medicines, October 2004

1298 Gershon Ben-Shakhar, Gary Bornstein, Astrid Hopfensitz and Frans van Winden, Reciprocity and Emotions: Arousal, Self-Reports, and Expectations, October 2004

1299 B. Zorina Khan and Kenneth L. Sokoloff, Institutions and Technological Innovation During Early Economic Growth: Evidence from the Great Inventors of the United States, 1790 - 1930, October 2004

1300 Piero Gottardi and Roberto Serrano, Market Power and Information Revelation in Dynamic Trading, October 2004

1301 Alan V. Deardorff, Who Makes the Rules of Globalization?, October 2004

1302 Sheilagh Ogilvie, The Use and Abuse of Trust: Social Capital and its Deployment by Early Modern Guilds, October 2004

1303 Mario Jametti and Thomas von Ungern-Sternberg, Disaster Insurance or a Disastrous Insurance - Natural Disaster Insurance in France, October 2004

1304 Pieter A. Gautier and José Luis Moraga-González, Strategic Wage Setting and Coordination Frictions with Multiple Applications, October 2004

1305 Julia Darby, Anton Muscatelli and Graeme Roy, Fiscal Federalism, Fiscal Consolidations and Cuts in Central Government Grants: Evidence from an Event Study, October 2004

1306 Michael Waldman, Antitrust Perspectives for Durable-Goods Markets, October 2004

1307 Josef Honerkamp, Stefan Moog and Bernd Raffelhüschen, Earlier or Later: A General Equilibrium Analysis of Bringing Forward an Already Announced Tax Reform, October 2004 
1308 M. Hashem Pesaran, A Pair-Wise Approach to Testing for Output and Growth Convergence, October 2004

1309 John Bishop and Ferran Mane, Educational Reform and Disadvantaged Students: Are They Better Off or Worse Off?, October 2004

1310 Alfredo Schclarek, Consumption and Keynesian Fiscal Policy, October 2004

1311 Wolfram F. Richter, Efficiency Effects of Tax Deductions for Work-Related Expenses, October 2004

1312 Franco Mariuzzo, Patrick Paul Walsh and Ciara Whelan, EU Merger Control in Differentiated Product Industries, October 2004

1313 Kurt Schmidheiny, Income Segregation and Local Progressive Taxation: Empirical Evidence from Switzerland, October 2004

1314 David S. Evans, Andrei Hagiu and Richard Schmalensee, A Survey of the Economic Role of Software Platforms in Computer-Based Industries, October 2004

1315 Frank Riedel and Elmar Wolfstetter, Immediate Demand Reduction in Simultaneous Ascending Bid Auctions, October 2004

1316 Patricia Crifo and Jean-Louis Rullière, Incentives and Anonymity Principle: Crowding Out Toward Users, October 2004

1317 Attila Ambrus and Rossella Argenziano, Network Markets and Consumers Coordination, October 2004

1318 Margarita Katsimi and Thomas Moutos, Monopoly, Inequality and Redistribution Via the Public Provision of Private Goods, October 2004

1319 Jens Josephson and Karl Wärneryd, Long-Run Selection and the Work Ethic, October 2004

1320 Jan K. Brueckner and Oleg Smirnov, Workings of the Melting Pot: Social Networks and the Evolution of Population Attributes, October 2004

1321 Thomas Fuchs and Ludger Wößmann, Computers and Student Learning: Bivariate and Multivariate Evidence on the Availability and Use of Computers at Home and at School, November 2004 